\title{
ЕФЕКТИВНІСТЬ ВИКОРИСТАННЯ ЕНЕРГЕТИЧНОЇ ДОБАВКИ ЕNЕRGY-ТОР ДЛЯ ПІДВИЩЕННЯ ПРОДУКТИВНОСТІ ТА ВІДТВОРНОЇ ЗДАТНОСТІ МОЛОЧНОЇ ХУДОБИ
}

\author{
Супрун Ірина Олександрівна \\ кандидат сільськогосподарських наук, доцент \\ Національний університет біоресурсів і природокористування України \\ ORCID: 0000-0001-8105-1923 \\ E-mail: isuprun@nubip.edu.ua
}

Куриленко Юрій Федорович кандидат сільськогосподарських наук, технічний консультант ТОВ «Біохем Україна» ORCID: 0000-0002-4679-0242

E-mail: kurylenko@biochem.net

Доступним джерелом глюкогенної енергії для профрілактики порушень обміну речовин та виникнення кетозів $є$ nрепарат ENERGY-TOP, виробництва компанії Біохем, що складається з гліцерину, бетаїну, пропіонової та лимонної кислот. Метою даних досліджень було підтвердження ефективності використання даного препарату для підвищення молочної продуктивності, відтворної здатності та просрілактики кетозів у молочної худоби. Для підтвердження ефективності застосування препарату ENERGY-TOP та розробки рекомендацій щодо його використання для годівлі корів молочного напряму продуктивності ми провели науково-господарський експеримент на базі СТОВ «Промінь», Арбузинського району, Миколаївської обл. Упродовж перших 100 днів після отелення коровам (голштинської породи) дослідної та контрольної груп згодовували основний раціон для корів, які знаходяться на роздоюванні. Додатково до нього 35 первісткам і 35 коровам згодовували препарат, з розрахунку 250 грамів на голову на добу, який додавали до концентрованих кормів. В результаті використання енергетичної добавки середньодобовий надій корів зріс на 0,6 ка, а у первісток - на 0,8 ке. Якісні показники молочної продуктивності (вміст жиру та білка) суттєво не змінювалися: 3,7-3,65 \% та 3,12 -3,14 \% відповідно. Середнє підвищення найвищого добового надою склало 1,3 кг/гол. За період експерименту корови і первістки дослідної групи дали на 4900 ке молока більше порівняно з контрольною групою. Застосування преnарату ENERGY-TOP забезпечує підвищення рівня надоїв за рахунок збагачення кормів різними джерелами енергії. Використання енергетичної добавки знизило рівень клінічних і субклінічних кетозів у корів і первісток відповідно на 8 і 5\%. Додаткове насичення кормів енергією збільшує виробництво молока і покращує заплідненість корів та первісток на 7-10\% а рівень тільності (PR) корів первісток на 3-5\%, забезпечуючи додатковий економічний ефрект на наступну лактацію на рівні 42525 - 70875 грн.

Ключові слова: молочна худоба, транзитний період, кетоз, ENERGY-TOP, заплідненість, PR

DOI: https://doi.org/10.32845/bsnau.lvst.2021.4.27

Для високопродуктивних корів транзитного періоду (пізнього сухостійного періоду та новотільних) характерною особливістю є певна неузгодженість між нейрогуморальною та гормональною регуляцією функції споживання корму та синтезу молока. Потреба в енергії у корів помітно збільшується протягом останніх трьох тижнів перед отеленням. Це пов'язано зі швидким внутрішньоматковим ростом плоду та підготовкою до вироблення молозива. У цей період споживання корму в сухій речовині знижується до 1,65\% від живої маси. Внутрішні резерви корів спрямовані на забезпечення зростаючих потреб у енергії. Якщо нестача енергії не задоволена, знижується концентрація глюкози у плазмі крові, а жир накопичується у печінці. В результаті відбувається формування кетонових тіл. Концентрація кетонових тіл у крові та сечі збільшується. Велика кількість кетонових тіл в організмі веде до затримки посліду, післяпологового парезу, маститів, метриту, зміщенню сичуга, порушенню статевого циклу та погіршенню молочної продуктивності.

Потреба в енергії в період роздою корів також зростає в 3-5разів, оскільки вона затрачується на секрецію молока тоді як через стрес та ослабленість організму споживання сухої речовини корму суттєво зменшується. Тому для синтезу молока використовуються запаси жирового депо та білки м'язової тканини власного організму. При цьому відбувається інтенсивне окислення резервних жирів, яке супро-

воджується накопиченням кетонових тіл: оксимасляної, ацетооцтової кислот та ацетону. В кінцевому результаті це також призводить до захворювання новотільних корів на кетоз $[2,3,4]$.

Кетоз (ацетонемія) вважається найбільш поширеним захворюванням обміну речовин у корів транзитного періоду. Він зустрічається у $20 \%$ корів в період пізнього сухостою та новотільних, та є причиною збитків молочного скотарства. Причиною є помилки у годівлі наприкінці лактації та під час сухостійного періоду. Це веде до ожиріння корів і глюконеогенезової недостатності. Кетоз також супроводжується зниженням живої маси корів, погіршення їх відтворної функції та молочної продуктивності, а також збільшується ризик розвитку післяпологових захворювань під час ранньої лактації $[3$, $4,11]$.

Для профілактики порушень обміну речовин та виникнення кетозів застосовують різні енергетичні кормові добавки на основі гліцерину та пропіленгліколю. Потрібно враховувати, що в обміні речовин у печінці пропіленгліколь спочатку повинен перетворитися на гліцерин, адже біохімічно описано лише синтез глюкози з гліцерину, але не з пропіленгліколю.

Доступним джерелом глюкогенної енергії є препарат ENERGY-TOP, виробництва компанії Біохем, що складається з гліцерину, бетаїну, пропіонової та лимонної кислот. За 
рекомендаціями виробника препарат, зберігаючи смакові якості корму, перешкоджає самозігріванню монокорму, підтримує водний баланс в організмі корови тим самим знижуючи вплив теплового стресу, скорочує ріст дріжджів та цвілевих грибків у монокормі, сприяє зниженню втрат поживних речовин. Енергетична добавка виробляється у фрармацевтичній формі коричневої рідини із слабким запахом пропіонової кислоти. Гліцерин, безбарвна, гігроскопічна, солодка на смак, в'язка рідина, яка $є$ побічним продуктом виробництва біодизеля [10], як діюча речовина препарату, засвоюється в організмі без великих втрат і швидко використовується для глюконеогенезу. Солодкий смак гліцерину підвищує поїдання кормів, які оброблені препаратом та забезпечує високий вміст енергії. Гліцерин не чинить негативного ефекту на склад мікрофлори рубця, натомість має гепатопротекторний ефрект. Goff and Horst, 2001 [13] оцінили пероральний прийом гліцерину як допоміжний засіб у лікуванні кетозу в двох експериментах. У першому коровам вводили1, 2 або 3 л гліцерину через зонд. Через тридцять хвилин після прийому, рівень глюкози в крові корів підвищився на 16, 20 і 25\% відповідно. Goff and Horst, 2001 [15] вказали, що дренчування гліцерину не впливає на $\mathrm{pH}$ рубця. В іншому експерименті корови з діагнозом клінічного кетозу отримували 1 л рідкого гліцерину. У них спостерігали підвищення концентрації глюкози в крові, зниження виділення кетонових тіл із сечею та збільшення молочної продуктивності. Ці дані також підтверджують потенційну роль гліцерину як прекурсора глюкози в раціоні для корів транзитного періоду [15].

В експерименті 339 транзитними повновіковими голштинськими коровами в університеті штату Пенсільванія впродовж 21 дня після отелення згодовували сухий харчовий гліцерин (65\% гліцерину) в дозі 250 г на голову на добу [9]. За результатами досліду сухий гліцерин не вплинув на споживання корму, надої, якісні показники молочної продуктивності, концентрацію інсуліну в сироватці крові. Корови 3 експериментальної групи демонстрували більш позитивний енергетичний статус під час другого тижня лактації, про що свідчить вища концентрація глюкози в плазмі крові, нижча концентрація $\beta$-гідроксибутирату (BHBA) у плазмі та нижча концентрація кетонових тіл в сечі. Дослідники не помітили ніяких відмінностей у споживанні корму або молочній продуктивності протягом перших 3 тижнів лактації. Натомість було відмічено тенденцію до збільшення надоїв у корів, які отримували гліцерин, протягом 6 тижнів лактації, що свідчить про потенційну користь сухого гліцерину на енергетичний баланс і молочну продуктивність корів.

Іншим складовим компонентом препарату є бетаїн безводний, який використовується як джерело метильних груп для метилювання гомоцистеїну у печінці жуйних тварин. Метильні групи необхідні для утворення цистеїну та метіоніну для обміну речовин, утворення м'язевих волокон, вовни та молочної продукції, утворення фосфоліпідів та ацетилхоліну для росту та нормальної функції нервової системи, оптимізації використання жирових ресурсів. Бетаїн має осмопротекторні та гепатопротекторні властивості. Як осмопротектор підтримує водний та іонний баланс клітин організму, зменшуючи потребу в енергії раціону за рахунок нормалізації роботи печінки, кишкового епітелію та інших органів. Як гепатопротектор покращує детоксикаційну здатність печінки та сприяє регенерації печінкових клітин. Окрім цього, бетаїн впливає на жировий обмін. Мікрофолора рубця використовує бетаїн для утворення оцтової кислоти, яка є джерелом енергії та впливає на рівень жиру в молоці. Таким чином, бетаїн сприяє збільшенню параметрів продуктивності у молочних корів, кіз та овець (збільшенню кількості молока, сухої речовини в молоці та вмісту жиру в молоці).

Пропіонова кислота, як іще один компонент препарат ENERGY-TOP повільніше, ніж інші кислоти знижує рівень $\mathrm{pH}$, має високу біодоступну енергією, а також пригнічує зростання та розвиток пліснявих грибків і дріжджів у монокормі, являється глікопластичним джерелом енергії. Більша частина виробленої пропіонової кислоти використовується як консервант у продуктах, споживаних людиною, та у кормах для тварин. Однак можливості застосування пропіонової кислоти у харчовій промисловості обмежені через зміну смакових якостей готового продукту під її впливом. Тому для продуктів харчування та кормах для тварин зазвичай застосовуються іï солі (пропіонат амонію, пропіонат натрію та пропіонат кальцію).

У жуйних пропіонат викликає підвищення інсуліну в крові, але на відміну від інших глюкогенних речовин, інсулін не знижує ефективність поглинання печінкою. Відомо, що пропіонат як кормова добавка підвищує рівень глюкози [6, 16] і знижує ВНВА в крові $[12,14,16]$. Пропіонат $є$ глюкогенним фактором летких жирних кислот (VFA) в рубці і, за оцінками, засвоюється з крові за допомогою печінки з ефективністю до 95\%. Baird G. D. [6], Bergman E. N. [7], показали, що під час інфузії глюкози поглинання пропіонату печінкою у лактуюючої корови було достатньо ефрективним щоб врахувати весь вихід глюкози печінкою. Пропіонат також $€$ антикетогенним і підтверджено зменшує окислення неестерифікованих жирних кислот (NEFA) у печінці [5].

Schmidt, G. H., Schultz, L. H. [16] повідомляли, що згодовування 113 г пропіонату натрію від отелення до 42 днів лактації значно підвищує молочну продуктивність та рівень глюкози в крові на 21 і 35 день лактації, при значному зниженні кетонових тіл в крові на 7, 21, 35 і 49 дні лактації.

Goff et al. [12] повідомляли про тенденцію до зниження BНВА в крові на 2 і 10 день лактації для корів джерсейської породи, яким згодовували пропіонат кальцію.

Лимонна кислота у складі ENERGY-TOP використовується для поліпшення смакових якостей препарату та для отримання антимікробного ефекту. Органічні кислоти, які містяться у препараті ENERGY-TOP скорочують негативний вплив мікробів на поживну та органолептичну якість монокорму протягом тривалого часу, що дозволяє зменшити частоту роздачі корму до одного разу на добу.

За попередніми оцінками застосування ENERGYTOP сприяє збереженню оптимальної продуктивності, особливо у високопродуктивних корів; компенсує нестачу споживання енергії в період ранньої лактації, забезпечує правильний синтез молочного цукру і таким чином допомагає підтримати оптимальний вміст глюкози в крові.

Метою даних досліджень було підтвердження ефективності використання енергетичної добавки ENERGY-TOP для підвищення молочної продуктивності та відтворної здатності великої рогатої худоби молочного напряму продуктивності та профілактики кетозів.

Матеріали та методи досліджень. Для підтвердження ефективності застосування препарату ENERGY-TOP та розробки рекомендацій щодо його використання для годівлі корів молочного напряму продуктивності ми провели 
науково-господарський експеримент на базі СТОВ «Промінь», Арбузинського району, Миколаївської обл. Продуктивне стадо господарства налічує 1900 корів голштинської породи із середньою молочною продуктивністю 10500 кг молока на голову в рік. Всього до експерименту було залучено поголів'я 35 первісток та 35 корів голштинської породи. Контрольна та експериментальна групи розподілялися за принципом груп-аналогів. Протягом періоду згодовування препарату проводився регулярний моніторинг поїдання кормів, кількісних та якісних показників молочної продуктивності шляхом щодекадних контрольних доїнь. На п'ятий день лактації, через 3 години після вранішньої годівлі було отримано зразки крові яремної вени, у яких визначено концентрацію кетонових тіл [1,11].

Результати досліджень. Протягом перших 100 днів після отелення коровам (голштинської породи) згодовували основний раціон для корів, які знаходяться на роздоюванні. Додатково до нього 35 первісткам і 35 коровам згодовували препарат ENERGY-TOP, з розрахунку 250 грамів на голову на добу, який додавали до концентрованих кормів (табл. 1). Зоотехнічний аналіз якості кормів показав їх хорошу якість та відповідність вимогам.

Аналіз поїдання монокорму у контрольній та експериментальній групах свідчить на користь експериментальної групи (90\% проти 95\%), у якої корми мали кращі смакові якості завдяки використанню гліцерину та лимонної кислоти в складі енергетичної добавки.

Основним критерієм збалансованості годівлі для корів молочного напрямку продуктивності $€$ кількість та якість молочної продукції. 3 метою вивчення впливу препарату на молочну продуктивність ми проаналізували контрольні доїння за перші 100 днів лактації.

Таблиця 1

Раціон дійної корови на період використання добавки ENERGY-TOP

\begin{tabular}{|l|c|c|c|}
\hline \multicolumn{1}{|c|}{ Компонент } & Кількість, кг & Вартість 1 кг компонента раціону, грн & 3агальна вартість, грн \\
\hline Кукурудзяний силос, кг СР & 10,60 & $3,00^{*}$ & 31,8 \\
\hline Солома пшенична, кг СР & 0,74 & $1,00^{*}$ & 0,74 \\
\hline Сінаж люцерновий, кг СР & 5,00 & $3,75^{*}$ & 18,75 \\
\hline Кукурудза (зерно), кг & 3,80 & 5,00 & 19,0 \\
\hline Соєва макуха, кг & 3,80 & 12,00 & 45,6 \\
\hline Барда післяспиртова, кг & 1,40 & 6,00 & 8,40 \\
\hline Меляса, кг & 1,40 & 3,00 & 4,20 \\
\hline Кукурудзяний глютен, кг & 0,75 & 24,00 & 8,00 \\
\hline Крейда, кг & 0,15 & 2,50 & 0,37 \\
\hline Премікс, кг & 0,15 & 35,00 & 5,25 \\
\hline Сіль, кг & 0,15 & 2,50 & 0,37 \\
\hline Сода, кг & 0,15 & 12,00 & 1,8 \\
\hline ЕNЕRGҮ-ТОР, кг & 0,25 & 50,00 & 12,5 \\
\hline Всього, кг СР & 28,00 & - & 161,16 \\
\hline
\end{tabular}

*- в перерахунку за ке СР основних кормів

Проведений дослід показав, шо корови, які отримували енергетичну добавку, ефективніше використовували поживні речовини раціону для синтезу молока (табл. 2). Так, в результаті використання препарату ENERGY-TOP середньодобовий надій корів зріс на 0,6 кг, а у первісток - на 0,8 кг. На початок періоду використання препарату у первісток він складав 32,5 кг на голову на добу, після використання препарату підвищився до 33,3 кг молока на голову на добу. У корів другої та старше лактацій до застосування продукту молочна продуктивність становила 42,4 кг, після застосування - 43,0 кг. Якісні показники молочної продуктивності (вміст жиру та білка) суттєво не змінювалися: 3,7-3,65 \% та 3,12 -3,14 \% відповідно.

При порівнянні найвищих добових надоїв (на 30-60 день лактації) корів і первісток дослідної та контрольної груп відмічено збільшення максимальних значень до 36,7 кг молока у первісток та 46,7 кг у корів. Найвищий добовий надій в дослідній групі корів підвищився на 1,1 а у первісток - на 1, 5 кг. Таким чином, середнє підвищення найвищого добового надою склало 1,3 кг/гол. За період експерименту корови і первістки дослідної групи дали на 4900 кг молока більше порівняно з контрольною групою.

Непрямим показником прихованих кетозів є співвід- ношення вмісту жиру та білка в молоці. Критичною величиною, що $є$ основою підозри прихованого кетозу, служить величина 1,5. В контрольних групах первісток і корів дане співвідношення знаходиться в межах 1,17-1,19. В дослідних групах прослідковується тенденція до його зниження. Окремо нами в науково-господарському досліді було враховано рівень кетозів у контрольних та дослідних групах корів і первісток, вимірюючи кетонометром кількість кетонових тіл в крові на 5 день після отелення. Диференціація здорових і хворих тварин відбувалася згідно із наступною шкалою концентрації кетонових тіл: до 1,2 ммоль/л характеризувало здорову тварина; 1,2-3 ммоль/л виявляло субклінічний кетоз; більше 3 ммоль/д мали тварини із клінічним кетозом $[1,11]$. Згідно з нашими результатами, використання енергетичної добавки ENERGY-TOP знизило рівень клінічних і субклінічних кетозів у корів і первісток відповідно на 8 і $5 \%$.

Проаналізувавши заплідненість корів - показник кількості тільних корів з числа тих, яких осіменили за певний період у контрольній і дослідній групах, ми відмітили збільшення запліднюваності первісток на 10\%, а корів на $7 \%$ порівняно із контрольними групами. 
Вплив використання енергетичної добавки на молочну продуктивність та відтворну здатність молочних корів

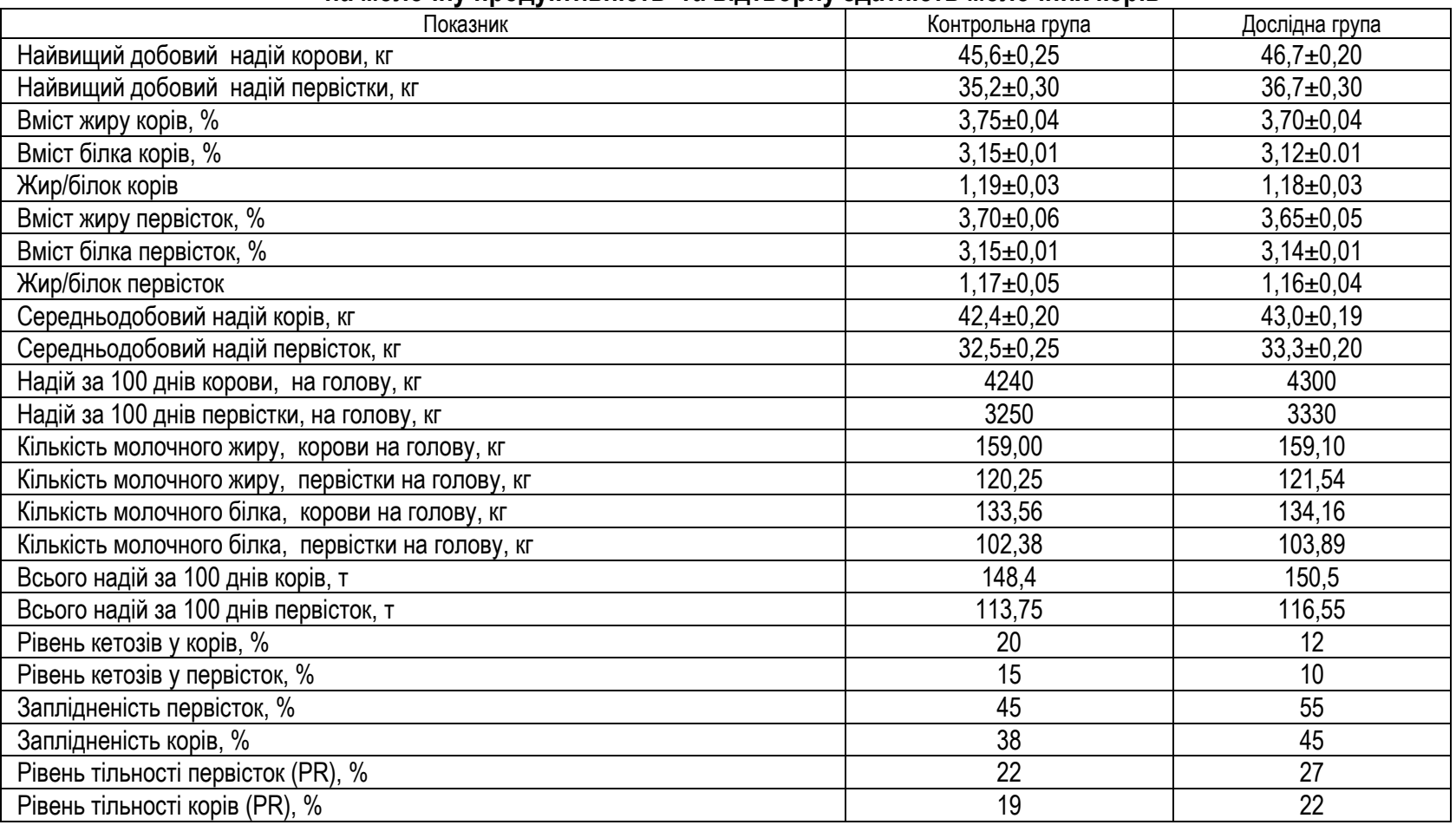

Дедалі більше господарств орієнтуються на такий показник відтворності здатності як рівень тільності у стаді (pregnancy rate (PR), \%. Цей показник характеризує статистичні дані, які показують співвідношення у відсотках кількості тільних корів з числа тих, яких осіменили за 21 день (середня тривалість циклу корови). Бажаним є отримання PR $>24 \%$ [8]. Проаналізувавши PR в дослідних та контрольних групах, можна зробити висновок, що у корів і первісток він поліпшився на 3-5\%. I хоча в стаді цей показник для корів все ще залишається досить низьким, але економічний ефект від застосування енергетичної добавки для корів і первісток можна буде отримати вже на наступну їх лактацію. Кожен відсоток підвищення PR дає додатковий прибуток на рівні 15 доларів [8]. Таким чином, економічний ефект від використання препарату для корів можна розрахувати наступним чином: 35 гол $3^{*} 15 \$=1575 \$$ (або 42525 грн). Для первісток відповідно економічний ефект від зростання PR буде становити 35 гол ${ }^{*}{ }^{*} 15=2625 \$$ (або 70875 грн).

Висновки. На основі проведених досліджень можна зробити висновок, що в умовах сучасного промислового тваринництва з метою профрілактики кетозів, підвищення молочної продуктивності та відтворної здатності потрібно включати до раціонів енергетичну добавку ENERGY-TOP.

Використання енергетичної добавки дає можливість знизити рівень клінічних і субклінічних кетозів у корів і первісток, а також забезпечує підвищення рівня надоїв за рахунок збагачення кормів різними джерелами енергії. Додаткове насичення кормів енергією збільшує виробництво молока і покращує заплідненість корів і первісток на 7-10\% та рівень отелення (PR) корів на 3 і первісток на 5\%, забезпечуючи додатковий економічний ефект на наступну лактацію на рівні 42525 - 70875 грн.

\section{Список використаної літератури:}

1. Баталова О. В. Содержание кетоновых тел и тиреоидных гормонов в крови коров при кетозе. Ветеринария, 2008, № 2, С. 43-45.

2. Кирилов М.П. Энергетические кормовые добавки в рационах высокопродуктивных коров. Главный зоотехник, 2006, №4, C.5-8.

3. Таропович А. Некоторые аспекты технологии кормления коров в переходный период. Молочное и мясное скотоводство, 2008, №1, С.9-12.

4. Шарвадзе Р.Л., Бабухадия К.Р., Бурмага А.В., Курков Ю.Б. Включение пропиленгликоля в рационы при раздое коров. Дальневосточный аграрный вестник, 2017, №3(43), C157-162. file:///C:/Users//rina/Downloads/vklyucheniepropilenglikolya-v-ratsiony-pri-razdoe-korov\%20(1).pdf

5. Armentano L.E., Grummer R.R., Bertics T.C., Skaar S.J., Donkin S.S. Effect of enefgy balance on hepatic capacity for oleate and propionate metabolism and triglyceride secretion. J. Dairy Sci., 1991, 74:132-139.

6. Baird G.D., Lomax A., Symonds H.W., Shaw S.R. Net hepatic and splanchnic metabolism of lactate, pyruvate and propionate in dairy cows in vivo in relation to lactation and nutrient supply. Biochem. J., 1980, 186:47-57.

7. Bergman E.N. Energy contribution of volatile fatty acids from the gastrointestinal track in various species. Physiol. Rev., 1990, 70(2):567-590. 
8. Cabrera V.E. Economic evaluation of reproductive performance. Journal of Dairy Science, 2015https://dairymgt.info/presentations/International_Audience/ReproductionEconomicsPaper.pdf

9. Chung Y.H., Rico D.E., Martinez C.M., Cassidy T.W., Noirot N., Ames A., Varga G.A. Effects of feeding a dry glycerin to early postpartum Holstein dairy cows on lactational performance and metabolic profiles. J. Dairy Sci., 2008, 90:5682- 5691.

10. Donkin S., Doane P. Glycerol as a feed ingredient for dairy cows. Tristate Nutrition Dairy Nutrition Conference, 2007, April 24 and 25.

11. Enjabert F., Necot M.C., Bayourthe C. Keton bodies in milk and blood of dairy cow; relationship between concentrations and utilization for detection of subclinical ketosis. J. Dairy Sc. 2001. - Vol. 84, № 3 - P. 583-589.

12. Goff J.P., Horst R.L., Jardon P.W., Borelli C., Wedam J. Field trials of an oral calcium propionate paste as an aid to prevent milk fever in periparturient dairy cows. J. Dairy Sci., 1996, 79:378-383.

13. Goff J.P., Horst R.L. Oral glycerol as an aid in the treatment of ketosis/fatty liver complex. J. Dairy Sci., 2001, 84(Suppl. 1):153.(Abstr.).

14. Linke P.L., DeFrain J.M., Hippen A.R., Jardon P.W. Ruminal and plasma responses in dairy cows to drenching or feeding glycerol. J. Dairy Sci., 2004, 87(Suppl. 1):343. (Abstr.)

15. Hippen A.R., De Frain J.M., Linke P.L. Glycerol and other energy sources for metabolism and production of transition dairy cows, [in:] Proc. 19th Annual Florida Ruminant Nutrition Symposium, Gainesville, FL, 2008.

16. Schmidt G.H., Schultz L.H. Effect of feeding sodium propionate on milk and fat production, roughage consumption, blood sugar and blood ketones of dairy cows. J. Dairy Sci., 1958, 41:169-175.

17. Shaw J.C. Ketosis in dairy cattle. J. Dairy Sci., 1956, 38:402-433.

\section{References:}

1. Batalova O.V. Soderzhanie ketonovyh tel $i$ tireoidnyh gormonov $v$ krovi korov pri ketoze. [Content of ketone bodies and thyroid hormones in the blood of cows in ketosis]. Veterinary, 2008, No. 2, pp. 43-45.

2. Kirilov M.P. Energeticheskie kormovye dobavki v racionah vysokoproduktivnyh korov. Glavnyj zootekhnik [Energy feed additives in the diets of high-yielding cows]. Glavnyj zootekhnik, 2006, No. 4, P.5-8.

3. Taropovich A. Nekotorye aspekty tekhnologii kormleniya korov v perekhodnyj period. [Some aspects of the technology of feeding cows in the transition period]. Molochnoe i myasnoe skotovodstvo, 2008, No. 1, P.9-12.

4. Sharvadze R.L., Babukhadia K.R., Burmaga A.V., Kurkov Yu.B. Vklyuchenie propilenglikolya v raciony pri razdoe korov. [The inclusion of propylene glycol in the diets when cows are milked]. Dal'nevostochnyj agrarnyj vestnik, 2017, No. 3 (43), P157162file:///C:/Users//rina/Downloads/vklyuchenie-propilenglikolya-v-ratsiony-pri-razdoe-korov\%20(1).pdf

5. Armentano, L.E., R.R. Grummer, S.J. Bertics, T.C. Skaar and S.S. Donkin. 1991. Effect of energy balance on hepatic capacity for oleate and propionate metabolism and triglyceride secretion. J. Dairy Sci. 74:132-139.

6. Baird, G.D., A. Lomax, H.W. Symonds and S.R. Shaw. 1980. Net hepatic and splanchnic metabolism of lactate, pyruvate and propionate in dairy cows in vivo in relation to lactation and nutrient supply. Biochem. J. 186:47-57.

7. Bergman, E.N. 1990. Energy contribution of volatile fatty acids from the gastrointestinal track in various species. Physiol. Rev. 70(2):567-590.

8. Cabrera Victor E. 2015. Economic evaluation of reproductive performance Journal of Dairy Science.https://dairymgt.info/presentations/International_Audience/ReproductionEconomicsPaper.pdf

9. Chung, Y.H., D.E. Rico, C.M. Martinez, T.W. Cassidy, N. Noirot, A. Ames and G.A. Varga. 2008. Effects of feeding a dry glycerin to early postpartum Holstein dairy cows on lactational performance and metabolic profiles. J. Dairy Sci. 90:5682- 5691.

10. Donkin, S. and P. Doane. 2007. Glycerol as a feed ingredient for dairy cows. Tristate Nutrition Dairy Nutrition Conference, April 24 and 25.

11. Enjabert, F. Keton bodies in milk and blood of dairy cow; relationship between concentrations and utilization for detection of subclinical ketosis / F. Enjabert, M. C. Necot, C. Bayourthe // J. Dairy Sc. 2001. - Vol. 84, № 3 - P. 583-589.

12. Goff, J.P., R.L. Horst, P.W. Jardon, C. Borelli and J. Wedam. 1996. Field trials of an oral calcium propionate paste as an aid to prevent milk fever in periparturient dairy cows. J. Dairy Sci. 79:378-383.

13. Goff, J.P. and R.L. Horst. 2001. Oral glycerol as an aid in the treatment of ketosis/fatty liver complex. J. Dairy Sci. 84(Suppl. 1):153.(Abstr.).

14. Linke, P.L., J.M. DeFrain, A.R. Hippen and P.W. Jardon. 2004. Ruminal and plasma responses in dairy cows to drenching or feeding glycerol. J. Dairy Sci. 87(Suppl. 1):343. (Abstr.)

15. Hippen A. R., De Frain J. M., Linke P. L. 2008. Glycerol and other energy sources for metabolism and production of transition dairy cows, [in:] Proc. 19th Annual Florida Ruminant Nutrition Symposium, Gainesville, FL

16. Schmidt, G.H. and L.H. Schultz. 1958. Effect of feeding sodium propionate on milk and fat production, roughage consumption, blood sugar and blood ketones of dairy cows. J. Dairy Sci. 41:169-175.

17. Shaw, J.C. 1956. Ketosis in dairy cattle. J. Dairy Sci. 38:402-433.

Suprun Iryna Alexandrovna, Candidate of Agricultural Sciences, Associate Professor, National University of Life and Environmental Sciences of Ukraine

Kurylenko Yurii Fedorovich, Candidate of Agricultural Sciences, technical consultant of Biochem of Ukraine Ltd

(Kyiv, Ukraine)

Efficiency of using an energy additive energy-top to increase productivity and reproductivity of dairy livestock

An available source of glycogenic energy for the prevention of metabolic disorders and ketosis is the drug ENERGY-TOP, 
manufactured by Biochem, consisting of glycerin, betaine, propionic and citric acids. The purpose of these studies was to confirm the effectiveness of this drug to increase milk productivity, reproducibility and prevention of ketosis. To confirm the effectiveness of the drug ENERGY-TOP and develop recommendations for its use for feeding dairy cows productivity, we conducted a scientific and economic experiment on the basis of LTD "Promyn", Arbuzyn district, Mykolaiv region. For the first 100 days after calving, the cows of Holstein breed of the experimental and control groups were fed the basic diet for dairy cows. In addition, 35 first-borns and 35 cows were fed the drug at the rate of 250 grams per head per day, which was added to concentrated feed. As a result of the use of energy supplements, the average daily yield of cows increased by $0.6 \mathrm{~kg}$, and the first-born - by $0.8 \mathrm{~kg}$. Qualitative indicators of milk productivity (fat and protein content) did not change significantly: $3.7-3.65 \%$ and $3.12-3.14 \%$, respectively. The average increase in the highest daily milk yield was $1.3 \mathrm{~kg} /$ head. During the experiment, cows and first-borns of the experimental group gave $4900 \mathrm{~kg}$ more milk compared to animals of the control group. The use of the drug ENERGY-TOP provides an increase in milk yield due to the enrichment of feed with various energy sources. The use of energy supplements reduced the level of clinical and subclinical ketosis in cows and first-borns by 8 and 5\%, respectively. Additional saturation of feed with energy increases milk production and improves fertility of cows and first-borns by $7-10 \%$ and calving (PR) of cows by 3 and first-borns by $5 \%$, providing additional economic effect on subsequent lactation at the level of 42525 - $70875 \mathrm{UAH}$.

Key words: dairy cattle, transit period, ketosis, ENERGY-TOP, fertility, PR

Дата надходження до редакції: 29.09.2021 р. 